\title{
Visit Wonosalam : Penguatan Potensi Wisata Desa Melalui Strategi Marketing Berbasis Syariah
}

\author{
Indrarini Rachma ${ }^{\# 1}$, Ridlwan Ahmad Ajeb ${ }^{\# 2}$, Aji Toni Seno ${ }^{\# 3}$, Canggih Clarashinta ${ }^{\# 4}$ \\ \# Jurusan Ilmu Ekonomi, Universitas Negeri Surabaya \\ 1 rachmaindrarinieunesa.ac.id
}

\begin{abstract}
Pengabdian Kepada Masyarakat ini berbasis pada kebutuhan dan keinginan warga desa sumberejo dan pangklungan wonosalam Jombang untuk mengembangkan potensi wisata di daerah mereka. Desa sumberejo dan Desa Pangklungan merupakan salah satu desa yang berada di wilayah Wonosalam Jombang dengan potensi wisata yang melimpah. Salah satu wisata di kawasan tersebut adalah goa sriti di desa sumberejo dan eco park di desa panglungan. Kawasan wisata tersebut, merupakan wisata yang baru yang pengelolaannya masih sederhana termasuk didalamnya adalah strategi pemasarannya. Sehingga PKM ini lebih difungsikan untuk menggajarkan kepada masyarakat terkait strategi pemasaran. Jombang merupakan kota santri, sebagian besar penduduknya adalah umat muslim sehingga potensi halal tourism atau wisata syariah memiliki peluang yang besar. Pada PKM ini strategi pemasaran yang akan di gunakan merupakan pemasaran berbasis syariah. Solusi yang ditawarkan adalah pendampingan pembuatan sistem informasi pemasaran untuk desa wisata tersebut. Program ini akan memberikan mempermudah desa dalam memasarkan pariwisatanya. Penerapan pemasaran yang dgunakan adalah pemasaran brbasis media sosial, strategi branding dan pemasaran syariah diharapkan dapat mengembangkan wisata di Wonosalam Jombang.
\end{abstract}

Keywords - Pemasaran Syariah, Wonosalam.

\section{Pendahuluan}

Pariwisata merupakan sektor yang sangat startegis dalam meningkatkan pendapatan suatu daerah. Dengan berkembangkanya pariwisata disuatu daerah, maka tidak hanya obyek wisata namun UMKM (Usaha Mikro Kecil Menengah) akan berkembang. Sebagai contoh adalah pariwisata di Daerah Istimiwa Yogyakarta, keindahan obyek wisata di Yogyakarta menarik minat wisatawan baik dalam negeri maupun luar negeri. Hal ini dapat meningkatkan pendapatan daerah. Akan tetapi tidak hanya pendapatan daerah disektor pariwisata yang meningkat, adanya wisatawan dalam negeri atau luar negeri akan menambah pendapatan UMKM seperti pendapatan pengerajin perak kotagede, pengrajin gerabah kasongan jogja, pengrajin batik jogja dan lain sebagainya. Sehingga pariwisata merupakan sektor strategis dalam mengembangkan suatu daerah.

Berikut adalah data Rangking Devisa Pariwisata Terhadap 11 Ekspor Barang Terbesar Tahun 2015.
TABEL 1

RANGKING DEVISA PARIWISATA TERHADAP 11 EKSPOR BARANG TEEBESAR TAHUN 2015

\begin{tabular}{|c|c|}
\hline \multicolumn{2}{|l|}{2015} \\
\hline Jenis Komoditas & $\begin{array}{c}\text { Nilai } \\
\text { (juta USD) }\end{array}$ \\
\hline Minyak \& gas bumi & $18,552.10$ \\
\hline "Batu bara & $15,943.00$ \\
\hline Minyak kelapa sawit & $15,385.20$ \\
\hline Pariwisata & $12,225.89$ \\
\hline Pakaian jadi & $7,371.90$ \\
\hline Makanan olahan & $6,456.30$ \\
\hline "Karet olahan & ' $5,842.00$ \\
\hline Alat listrik & $5,644.80$ \\
\hline Tekstil & $4,996.00$ \\
\hline "Kayu olahan & $3,815.80$ \\
\hline Kertas dan barang dr kertas & $\begin{array}{r}3,605.50 \\
-50\end{array}$ \\
\hline Bahan kimia & $2,807.60$ \\
\hline
\end{tabular}

Sumber: Kementrian Pariwisata, 2018 
Dari data diatas terlihat bahwa pariwisata merupakan salah satu sektor yang dapat menghasilkan devisa terbesar selain ekspor dan impor. Sehingga jika suatu daerah memiliki keinginan untuk meningkatkan pendapatan daerahnya maka mengembangkan potensi wisata merupakan hal yang baik dilakukan.

Jawa Timur merupakan salah satu daerah yang sedang mengembangkan potensi wisata sebagai salah satu upaya dalam meningkatkan pendapatan daerah dan pengembangan UMKM. Setiap kota di Jawa Timur memiliki obyek wisata unggulan seperti Banyuwangi dengan pantai merah, Sumenep dengan gili labak, Batu dengan kebun apel dan Jombang dengan daerah wonosalam.

Wonosalam merupakan salah satu kecamatan di kabupaten Jombang. Memiliki potensi wisata yang indah dengan wilayah pegunungan dan penghasil buah durian terbesar di Jawa Timur, merupakan daerah yang sedang mengembangkan potensi wisatanya. Dua desa di kecamatan wonosalam yang memiliki potensi pariwisata besar adalah desa sumberejo dan desa panglungan. Desa Sumberejo memiliki potensi wisata desa yang belum dikelola dengan maksimal. Salah satu potensi wisata yang terdapat di desa Sumberejo adalah wisata goa Sriti yang terletak di dusun Sidolegi. Goa Sriti ditemukan warga di Lembah Pegunungan Anjasmoro. Berdasarkan keterangan warga, sebenarnya Goa Sriti yang berada di dalam area hutan milik Perhutani telah puluhan tahun keberadaannya diketahui warga sekitar. Namum sulitnya akses menuju goa dan mulut goa tertutup rerumputan. Setelah warga gotong royong untuk membuka akses menuju goa, akhirnya dapat menjadi alternatif wisata baru di kawasan Wonosalam. Berdasarkan keterangan bapak Abdul Sholeh, kepala dusun Sidolegi Desa Sumberjo Kecamatan Wonosalam mengatakan bahwa wisata Goa Sriti termasuk wisata alam yang baru. Saat ini goa tersebut dikelola oleh desa melalui swadaya masyarakat secara tradisional. Dikarenakan goa sriti merupakan obyek wisata baru, maka pemasaran merupakan hal penting yang harus dilakukan dan hal tersebut belum terfasilitasi dengan baik.

Tidak hanya desa sumberejo di kecamatan wonosalam saja yang memiliki potensi wisata namun desa panglungan di kecamatan wonosalam juga memiliki potensi wisata yang indah. Potensi Wisata di desa pangklungan cukup banyak, beberapa diantaranya adalah eco park. kawasan eco park merupakan kawasan goa sigolo - golo pangklungan. Kawasan ini dikelola oleh warga desa khususnya karang taruna, sehingga untuk pemasaran masih terbatas.

Berdasarkan penjelasan di atas, terdapat beberapa permasalahan dalam meningkatkatkan potensi pariwisata di desa sumberejo dan panglungan yakni pengelolaan wisata yang masih bersifat tradisional dan pemasaran pariwisata yang belum optimal sehingga kurang dikenalnya obyek wisata desa sumberejo dan panglungan. Untuk itu perlu dilakukan pelatihan pengelolaan wisata dan strategi pemasaran agar dapat meningkatkan jumlah pengunjung yang ada dan pada akirnya meningkatkan pendapatan daerah khususnya kecamatan wonosalam. Akan tetapi pada
Pengabdian Kepada Masyarakat tahun 2018 ini akan lebih difokuskan pada pelatihan strategi pemasaran berbasis Syariah untuk meningkatkan jumlah wisatawan.

\section{TARGET DAN LUARAN}

Target dalam Pengadian Kepada Masyarakat ini adalah perangkat desa, karang taruna dan pengelola wisata desa sumberejo dan desa panglungan kecamatan wonosalam Jombang. Dalam kegiatan sosialisasi ini target peserta sebanyak 50 orang.

Tujuan dari kegiatan ini adalah untuk membantu masyarakat dalam memasarkan wisata daerahnya sehingga dapat meningkatkan pendapatan. Media pemasaran yang akan disosialisasikan adalah media kreatif berbasis online seperti facebook, Instagram, youtube dan lain - lain. Sehingga luaran dari kegiatan ini adalah perangkat desa, karang taruna dan pengelola wisata dapat memahami pemasaran berbasis Syariah dengan media kreatif.

\section{METODE PELAKSANAAN}

Kegiatan pengabdian Kepada Masyarakat ini dilaksanakan melalui beberapa tahapan yakni :

\section{A. Analisis kebutuhan dan pendataan peserta}

Kegiatan ini diawali dari survey ke desa sumberejo dan desa panglungan wonosalam Jombang. Pada saat survey, surveyor bertemu kepala desa dan menanyakan kebutuhan desa terkait penengembangan potensi wisata. Hasil survey menyatakan bahwa dewa sumberejo dan panglungan membutuhkan sosiaslisai terkait dengan pemasaran dengan sasaran perangkat desa, karang taruna dan pengelola wisata.

\section{B. Penyiapan lokasi, sarana dan prasarana}

Untuk kelancaran kegiatan pelatihan, maka dilakukan penyiapan lokasi dan prasarana pelatihan. Dalam kegiatan Pengabdian Kepada Masyarakat ini kepala desa dan perangkat desa berperan aktif dan sangat membantu kelancaran kegiatan. Sarana dan prasarana kegiatan pelatihan meliputi ruangan dan jaringan wifii disediakan oleh perangkat Desa panglungan. Tim pelaksana kegiatan mempersiapkan materi dan modul.

\section{Pelaksanaan kegiatan}

1) Sosialisasi strategi marketing berbasis Syariah: Kegiatan sosialisasi dilaksanakan pada hari rabu tanggal 25 Juli 2018 pukul 14.00 WIB di Balai desa panglungan Kecamatan wonosalam jombang. Peserta yang hadir berasal dari perangkat desa sumberejo dan panglungan wonosalam Jombang, karang taruna serta pengelola wisata keseluruhan peserta berjumlah 47 orang. Kegiatan sosialisasi ini dibagi menjadi dua yakni sosialisasti teori pemasaran berbasis Syariah yang disampaian oleh bapak Ahmad Ajeb R, S.Pd., M.SEI selama satu jam dan dilanjutkan materi terkait media pemasaran kreatif dengan media sosisal seperti facebook, 
Instagram dan youtube oleh Dr. Toni Seno Aji selama kurang lebih satu setengah jam.
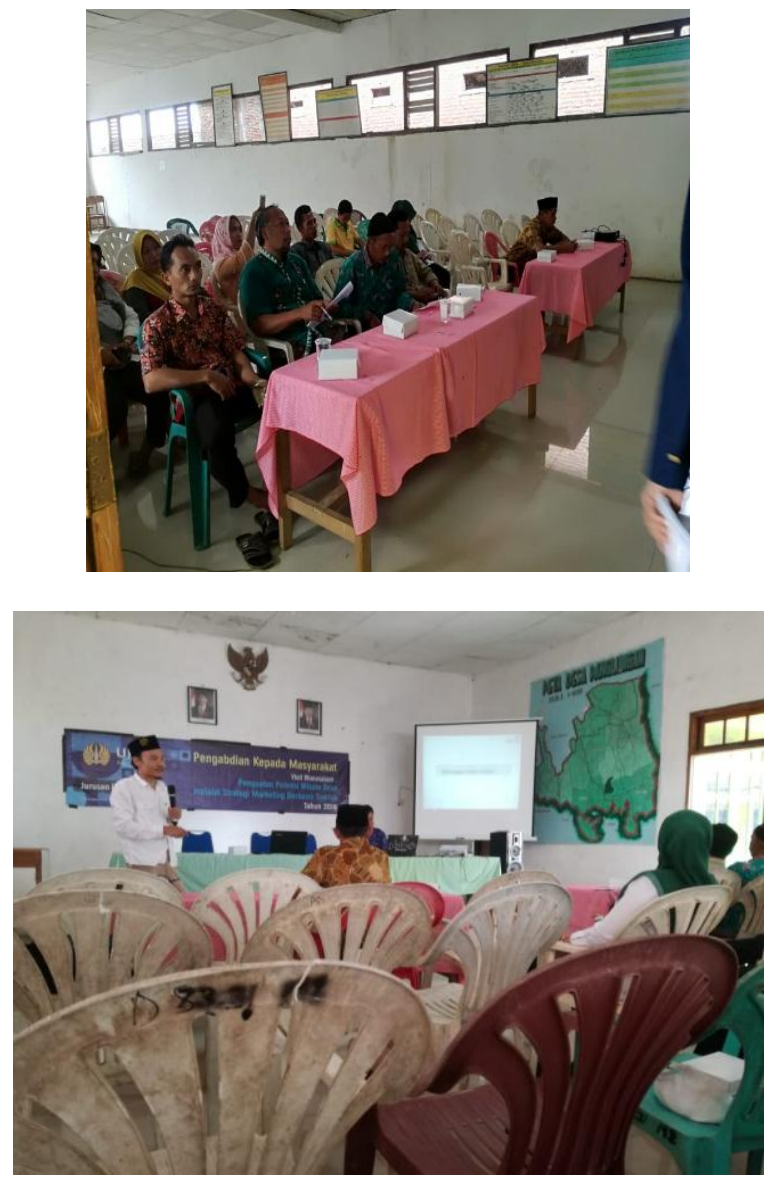

Gambar 1

Kegiatan Sosialisasi Pemasaran Berbasis Syariah

2) Hasil dan luaran: Kegiatan strategi marketing berbasis Syariah memperoleh hasil dan luaran yaitu Modul pelatihan dan Publikasi pada Jurnal pengabdian masyarakat.

\section{Kelayakan Perguruan Tinggi}

Kegiatan Lembaga Penelitian dan Pengabdian Masyarakat (LPPM) Universitas Negeri Surabaya yang berkaitan dengan pengabdian kepada masyarakat sangat bermanfaat bagi pemberdayaan masyarakat, baik dalam bidang pendidikan, sosial, seni, budaya maupun ekonomi. Lembaga Pengabdian Kepada Masyarakat (LPM) Universitas Negeri Surabaya selama ini telah telah dipercayai oleh pemerintah pusat, daerah, dan instansi-instansi negeri maupun swasta dalam kegiatan penelitian dan pengabdian kepada masyarakat

\section{HASIL DAN PEMBAHASAN}

Kegiatan pengabdian pada masyarakat di desa Sumberejo dan desa Panglungan Wonosalam Jombang ini dilaksanakan berdasarkan hasil komunikasi dan diskusi dengan kepala desa dan perangkat desa berdasarkan analisis kebutuhan. Kegiatan sosialisasi ini memberikan hasil sebagai berikut: (1) perangkat desa, karang taruna dan pengelola wisata desa sumberejo dan panglungan mengerti dan memahami terkait pemasaran (branding) dengan prinsip syariah;(2) perangkat desa, karang taruna dan pengelola wisata desa sumberejo dan panglungan dapat mengerti cara menggunakan media kreatif (media sosial seperti facebook, Instagram, youtube) dalam memasarkan wisata;(3) perangkat desa, karang taruna dan pengelola wisata desa sumberejo dan panglungan dapat menggunakan media kreatif (media sosial seperti facebook, Instagram, youtube). Ketiga hasil tesebut dapat tercermin dalam instrument persepsi peserta yang menunjukan penilaian positif sebagai berikut.

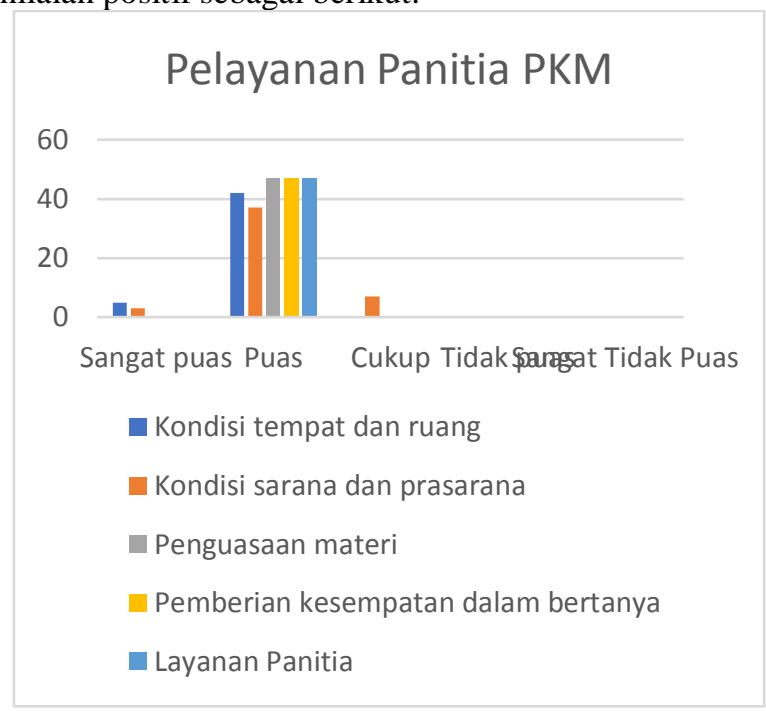

Gambar 2. Grafik Pelayanan Panitia PKM (Sumber : Hasil olah data)

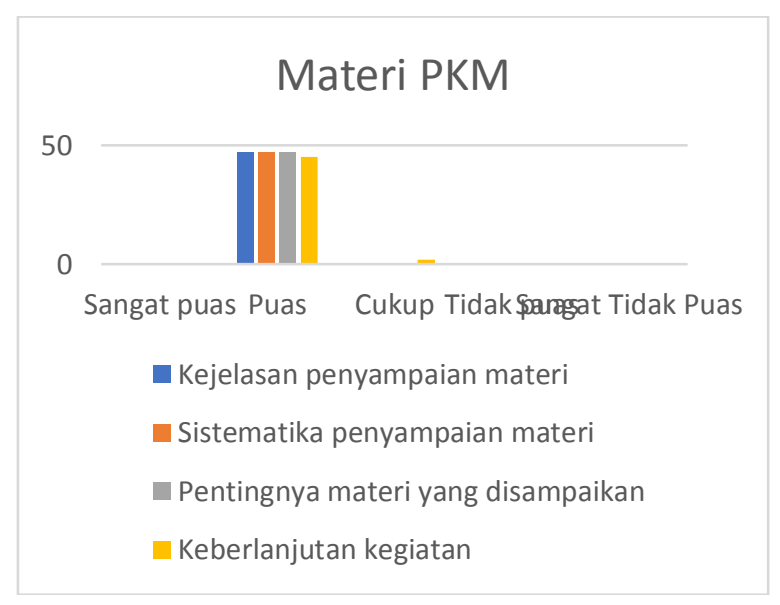

Gambar 3. Grafik Materi PKM (Sumber: Hasil olah data )

Berdasarkan grafik diatas dapat disimpulkan bahwa masyarakat puas terhadap kgiatan sosialisasi pemasaran berbasis Syariah baik dari segi pelayanan tim PKM serta materi yang diberikan oleh TIM. 


\section{KESIMPULAN}

Berdasarkan hasil pelaksanaan kegiatan program Pengabdian Masyarakat dapat disimpulkan bahwa:

- Sosialisasi pemasaran berbasis Syariah dapat meningkatkan kemampuan para perangkat desa, karang taruna dan pengelola wisata dalam melakukan pemasaran obyek wisata.

- Berdasarkan hasil sosialisasi dilakukan dalam dua tahapan penyampaian materi teori pemasatan berbasis Syariah dan materi penerapan pada media kreatif

- Respon peserta sosialisasi terhadap kegitan yang dilakukan cukup baik terlihat dari instrument persepsi peserta.

\section{DAFTAR PUSTAKA}

[1] Rustan, S., 2009. Mendesain Logo, Jakarta: Gramedia Pustaka Utama.

[2] Tinarbuko, S., 2009. Iklan Politik dalam Realitas Media, Yogyakarta: Jalasutra.

[3] Wasesa, S.A., 2011. Political Branding \& Public Relations: Saatnya Kampanye Sehat, Hemat, dan Bermatabat, Jakarta: Gramedia Pustaka Utama 